\title{
Stalk-Juice Quality Traits of Sweet Sorghum as Affected by Season in Sudan
}

\author{
Salma I. Abdalbagi ${ }^{1, a}$ and Maarouf I. Mohammed ${ }^{2, b^{*}}$ \\ ${ }^{1}$ Forage \& Range Research Program, Shambat Research Station, Khartoum, Sudan. \\ ${ }^{2}$ Forage Improvement Program, Agricultural Research Corporation (ARC), Khartoum North, Sudan. \\ as salmaebrahim25@hotmail.com, bmaaroufibrahim@gmail.com
}

Keywords: Brix, pol, reducing sugars, purity, syrup, jaggery

\begin{abstract}
An experiment was conducted in Shambat (2012-2013) during the summer and winter seasons to study the stalk-juice quality parameters of 29 exotic and local sweet sorghum varieties as affected by season. The objectives were to provide basic data attributing to syrup and sugar (jaggery) production in the Sudan. The materials were arranged in RCB design. Data were collected on brix, pol (sucrose \%), reducing sugars, total sugars, purity and $\mathrm{pH}$. The single and combined analysis of variance revealed highly significant differences among varieties for all traits studied. The variety $\mathrm{x}$ season interaction was significant for all traits other than total sugars $\%$, implying the need for considering the variety choice in each season. The results of juice quality parameters were mostly within the range reported in the literature. The exotic materials excelled the local ones in brix, pol\%, total sugars $\%$ and purity. The exotic varieties: N100, Red-X, Hastings and N110 as well as the local Ankolib selections: AnkNyala and Ank36 were identified as having juice quality traits suitable for syrup production. The exotic varieties: BlueRibbon, KansasCollies and Brawley were identified for sugar (jaggery) production. It was concluded that interaction of variety x season and yield parameters for juice, grain and stover should be considered when determining the choice of the variety. Future research should focus on developing multi-purpose varieties capable for concurrent production of syrup/sugar, grain and stover.
\end{abstract}

\section{Introduction}

Sorghum (Sorghum bicolor (L.) Moench) is a crop of world-wide importance. It ranks fifth in importance as a grain cereal. It is the most qualified crop in meeting the demand for large quantities of high-quality fodders, especially in the drier parts of the world [1] with unique ability to produce under a wide array of harsh environmental conditions [2]. Sweet sorghum is a type of sorghum characterized by ability to accumulate sweet juice in the stalk. It was first introduced to USA more than a century ago with the primary aim of manufacturing crystalized sugar, but due to some technical difficulties the emphasis switched to syrup production before being further shifted to forage production. Recently, sweet sorghum also appeared to have great potential as an annual energy crop.

The agro-industrial potentials of sweet sorghums have been discussed by many workers. The crop offers great potential for multi-purpose uses mainly for syrup, forage and ethanol production [3]. Plant breeders in the United States, India and China have developed high-brix cultivars to increase the potential of this crop for syrup production. Excellent syrup can be made from sweet sorghum when brix of raw juice is greater than 15\% [4]. Syrup yields ranging 800-1900 L/ha have been reported depending on weather conditions [3]. Sweet sorghum provides options for concurrent food, feed and sugar production and is suitable for smallholder farmer cultivation on less-favored lands. Although sugar content declines by about $25 \%$ at grain maturity, this is, however, compensated for by the added gain from grain-income [5].

In Sudan, sorghum is the most important crop grown for food and feed. Sudan is believed to be one of the major centers of sorghum domestication and diversification [6,7]. 'Ankolib' is the vernacular name for sweet sorghum. It is a highly diverse population belongs to race durra-bicolor characterized by sweet stalk just like sugar cane [8]. Developing improved grain or forage types have 
been the main focus of research efforts in Sudan. Attempts to investigate traits attributing to syrup production from sweet sorghum are specifically lacking. Mohammed and Mohamed [9] evaluated exotic and locally developed genotypes for forage attributes. Concurrent improvement of stem-sugar, stover and grain yield was also studied in Sudanese and exotic sorghums [10,11].

The present study aimed to evaluate stalk-juice quality parameters of sweet sorghum as affected by season in Sudan. The ultimate objectives were to provide some basic data that may contribute to syrup and/or sugar (jaggery) production in Sudan.

\section{Materials and Methods}

\section{The experimental site}

The study was conducted in the Experimental Farm of the Agriculture Research Corporation (ARC) at Shambat (latitude $15^{\circ} 39^{\prime} \mathrm{N}$; longitude $32^{\circ} 31^{\prime} \mathrm{E}$; altitude $380 \mathrm{~m}$ above sea level) during the summer of 2012 and winter of 2012/2013. The soil is heavy clay, non-saline, non-sodic with $\mathrm{pH}$ of 7.9-8.5.

\section{The growing seasons}

The major features of the climatic conditions prevailed during the growing seasons are depicted in Fig. 1. The winter season is drier than the summer with no precipitations.

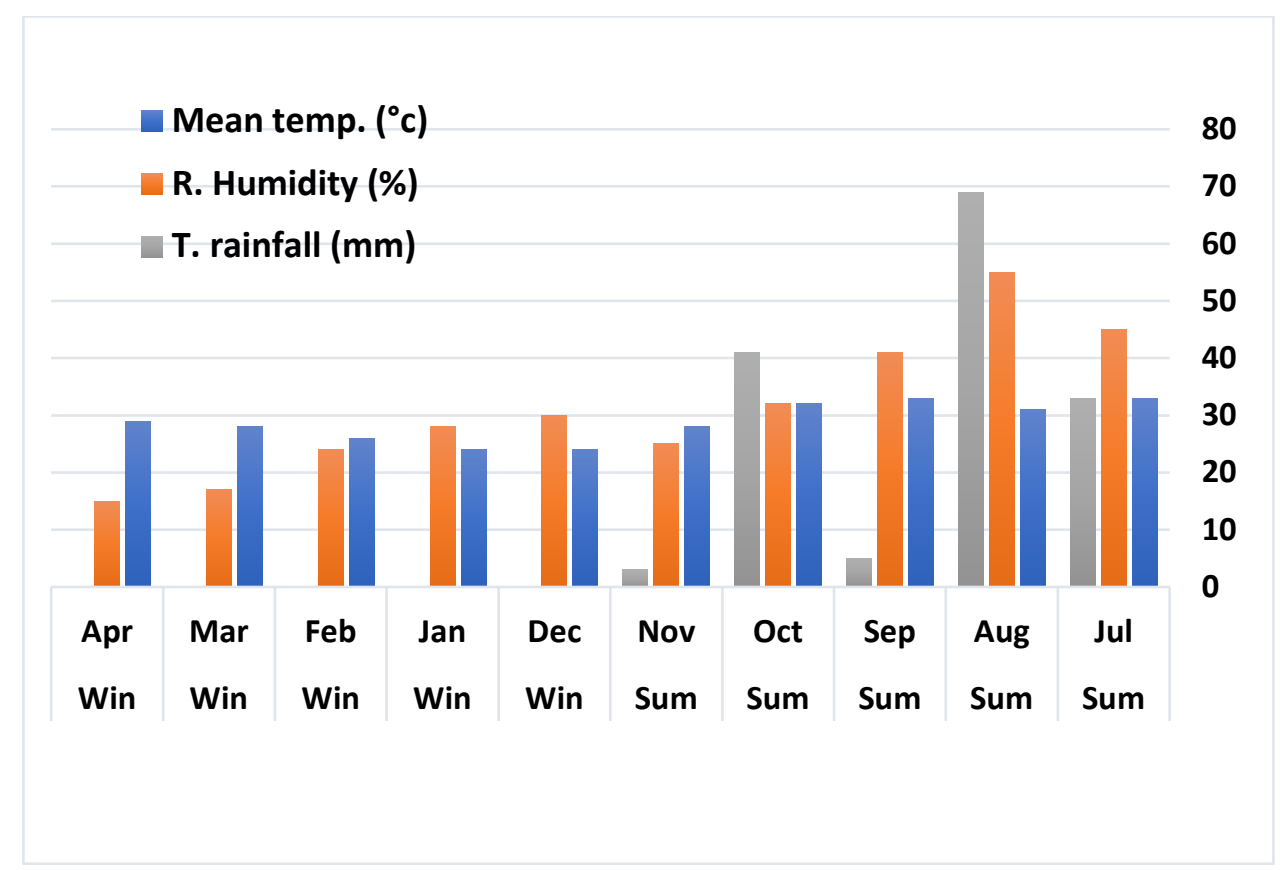

Fig. 1. The major features of climatic conditions of the growing seasons

\section{The plant materials}

The plant materials consisted of 29 sorghum genotypes representing 4 groups (Table 1). The genotypes 1-15 are exotic sweet sorghum materials. The genotypes 16-29 were locally developed by selection within local populations of Ankolib, Sudan grass and Abu Sabin. Selection was practiced for juiciness (green mid-rib) and other forage attributes.

\section{Management and experimental design}

Sowing dates were on 22/July/2012 and 6/Dec/2012 for the summer and winter sowings, respectively. The materials were arranged in RCB design with 3 replicates. The plot was composed of two ridges $5 \mathrm{~m}$ long. Planting was done by placing 5 seeds in holes spaced $0.7 \mathrm{~m} \mathrm{x} 0.2 \mathrm{~m}$. The trials were watered at 7 to 10 days interval. Nitrogen fertilizer (urea) was added at the second irrigation at 
a rate of $55 \mathrm{~kg} \mathrm{n} / \mathrm{ha}$. The insecticide Sevin (Carbaryl $85 \mathrm{WP}$ ) was sprayed against stem borers one month after sowing. Weed population was kept to minimum by hand removal.

Table 1. Sorghum genotypes used in the study

\begin{tabular}{|c|c|c|c|}
\hline Entry & Genotypes & Source & Group / Type \\
\hline 1 & N98 & USDA / U.of Nebraska & Sweet sorghum \\
\hline 2 & N99 & " & Sweet sorghum \\
\hline 3 & KansasCollies & ” & Sweet sorghum \\
\hline 4 & BlueRibbon & ” & Sweet sorghum \\
\hline 5 & Hastings & $"$ & Sweet sorghum \\
\hline 6 & Red-x & ” & Sweet sorghum \\
\hline 7 & Waconia-L & $"$ & Sweet sorghum \\
\hline 8 & Fremont & ” & Sweet sorghum \\
\hline 9 & Brawley & $"$ & Sweet sorghum \\
\hline 10 & SugarDrip & $"$ & Sweet sorghum \\
\hline 11 & N110 & ” & Sweet sorghum \\
\hline 12 & N100 & ” & Sweet sorghum \\
\hline 13 & Colman & 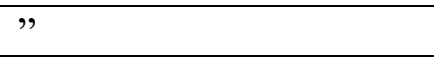 & Sweet sorghum \\
\hline 14 & E-35-1 & $"$ & Sweet sorghum \\
\hline 15 & AGSilo200 & Marketplace & Sweet sorghum \\
\hline 16 & Ank18 & FIP-Shambat* & Ankolib \\
\hline 17 & Ank43 & $"$ & Ankolib \\
\hline 18 & Ank36 & $"$ & Ankolib \\
\hline 19 & AnkNyala & Niyala Research Station & Ankolib \\
\hline 20 & SG32-2a & FIP-Shambat & Sudan grass \\
\hline 21 & SG54 & $"$ & Sudan grass \\
\hline 22 & SG33 & $"$ & Sudan grass \\
\hline 23 & SG12-1 & $"$ & Sudan grass \\
\hline 24 & S.70 & $"$ & Abu Sabin \\
\hline 25 & S.158 & ” & Abu Sabin \\
\hline 26 & S.154 & 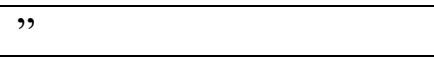 & Abu Sabin \\
\hline 27 & S.126 & $"$ & Abu Sabin \\
\hline 28 & S.134 & " & Abu Sabin \\
\hline 29 & Kambal & FIP-Shambat & Abu Sabin \\
\hline
\end{tabular}

*: Forage Improvement Program, Shambat Research Station, Sudan

\section{Juice collection and preparation}

The Juice was collected from the first press of the cane produced in the whole plot when each variety reached physiological maturity of the grain. The plants were cut $5-7 \mathrm{~cm}$ above ground level. The panicles were removed and leaves (blade + sheath) were stripped off. The fresh cane was immediately taken to the lab where it was washed, left to dry for a while and then passed through hand driven two-roller mill. The juice received was filtered using muslin cloth. The juice was kept in tightly closed plastic bottles, labeled and stored under deepfreeze condition for future investigations.

\section{Data collection}

The juice analysis was carried out in the laboratory of Kenana Sugar Factory, Rabak, Sudan. The following juice quality traits were determined:

Brix (\%): The brix (total soluble solids) was recorded from samples taken from the entire volume of the extracted juice using digital refractometer RFM 340. 
Pol \%: The sucrose percentage of the juice (Pol) was estimated following Horne's dry lead acetate clarification method [12] using automatic polarimeter (AP-300).

Reducing sugar \%: Reducing sugars (invert sugars) were estimated using dinitro-salicylic acid (DNSA) method [13]. in a sample.

Total sugars \%: Calculated as the combined percentages of sucrose and reducing sugars

Purity \%: Measured as apparent purity using the formula: (pol x 100)/Brix

pH: Recorded from $200 \mathrm{ml}$ sample of juice using $\mathrm{pH}$ meter.

\section{Statistical Analysis}

The data collected were subjected to single analysis of variance (ANOVA) before performing the combined ANOVA following the standard procedure of analyzing RCB design ([14]. Least Significant Difference (LSD) procedure was used to separate the means. The statistical package GenStat [15] was used to run the analysis.

\section{Results}

Tables 2 and 3 show mean squares for studied traits resulting from single and combined ANOVA, respectively. Differences among genotypes were mostly highly significant for all traits in single and combined analysis. Apart from total sugars, genotype $\mathrm{x}$ season (GxE) interaction was significant, specifically for reducing sugars and $\mathrm{pH}$ where it was highly significant.

Brix (\%): The average brix in winter and summer seasons (Table 4) were $16.81 \%$ and $16.05 \%$, respectively. The exotic sweet sorghum varieties performed better than the local ones in brix percentage. Three exotic varieties, namely: Brawley, BlueRibbon and KansasCollies gave above 20\% brix in both seasons, with overall average of $21.42 \%, 21.39 \%$ and $20.63 \%$, respectively. Of the local materials, the best performing were 3 varieties belong to Ankolib group, namely: Ank36, Ank18 and AnkNyala with respective average of $18.75 \%, 17.99 \%$ and $17.62 \%$. The lowest brix values were obtained by the local varieties S.70 and Ank43, averaging 11.6\% and 12.34\%, respectively.

Pol (\%): The average pol in winter and summer seasons (Table 5) were $8.01 \%$ and $7.55 \%$, respectively. The exotic varieties: BlueRibbon, KansasCollies and Brawley showed the highest pol in both seasons, averaging $16.37 \%, 15.38 \%$ and $14.18 \%$, respectively. Some exotic varieties gave pol range of $10 \%$ - 11\%, viz: Hastings, N110, Red-X and Waconia-L. Among the local varieties, the highest pol average was shown by the Ankolib varieties, viz: Ank36 (11.42\%), AnkNyala (9.74\%) and Ank 18 (8.05\%). Pol average of 5 to $6 \%$ were shown by SG32-2a, S.158 and Kambal. The lowest pol was shown by the Abu Sabin varieties: S.154 (1.96\%) and S.70 (2.33\%).

Reducing Sugars\%: Reducing sugars (Table 6) averaged $6.75 \%$ and $5.95 \%$ in winter and summer seasons, respectively. Among exotic materials, BlueRibbon, Brawley and KansasCollies displayed the lowest reducing sugars $\%$ in both seasons averaging $3.95 \%, 4.18 \%$ and $4.23 \%$, respectively. Above average values were displayed by Hastings $(6.70 \%)$, Red-X $(6.70 \%)$ and N110 (6.53\%). Most of the local materials, specially Abu Sabin and Sudan grass groups displayed above average values of 6.5\%-10.0\%. The Ankolib variety Ank18 averaged 5.18\% whereas AnkNyala and Ank 43 gave an average of $6.85 \%$. Some varieties showed differential performance in reducing sugar, i.e. N100 and SugarDrip displaying $10.0 \%$ during winter vs $5.35 \%$ and $4.50 \%$ during summer, respectively.

Total sugars \%: Total sugars (Table 7) amounted to $14.77 \%$ and $13.49 \%$ in winter and summer seasons, respectively. The highest varieties in total sugars were BlueRibbon, KansasCollies, Brawley and Hastings averaging between $18.20 \%$ to $20.32 \%$. The varieties N110, N100 and Red-X 
came next averaging from $17.53 \%$ to $17.64 \%$. The Ankolib variety Ank36 averaged $16.60 \%$. S.158 (Abu Sabin) and SG32-2a (Sudan grass) averaged 13.93\% and $12.89 \%$, respectively.

Purity \%: The average values obtained for purity (Table 8 ) in both seasons were around $45 \%$. The highest purity averages were shown by BlueRibbon (76.25\%) and KansasCollies (74.50\%). Brawley showed purity of 65.20\%. Apart from Ank36 (61.00\%) and AnkNyala (53.27\%), most of the local materials displayed below average purity. The purity of Abu Sabin group varied between $14.25 \%$ (S.154) and 40.26\% (S.158).

pH: The pH averaged 5.298 and 5.401 in winter and summer seasons, respectively (Table 9). The overall average of $\mathrm{pH}$ was 5.349. KansasCollies showed the lowest $\mathrm{pH}$ (4.947). The highest $\mathrm{pH}$ was shown by S.126 (5.742). Apart from SugarDrip (5.378) and AGSilo200 (5.343) all of the exotic materials showed below average $\mathrm{pH}$ whereas the opposite is true for the local ones. Generally, most varieties displayed lower $\mathrm{pH}$ in winter than summer season.

\section{Discussion}

Variability: The highly significant differences among genotypes for juice quality parameters indicated that most of the variability observed were attributable to genetic differences. However, GxE was also significant, pointing to the differential performance of genotypes for all traits other than total sugars. Therefore, although some varieties have similar performance across seasons, the choice of variety should be considered in each season separately for traits other than total sugars. Similar results showing variety $\mathrm{x}$ season interaction for juice quality parameters in sweet sorghum were reported [16].

Juice quality performance: With few exceptions, the results of juice quality parameters obtained in this study were within the range reported in the literature. The brix values which indicates total soluble solids were near to those reported by Almodares and Hatamipour (11.6\%-23.01\%) [17]; apparently higher than those reported by Balole (8.3\%-15.1\%) [18] and slightly lower than those of Kulkarni et al. (15\%-23\%) [19]. The results of pol which indicates the sucrose percentage were within the range of those reported by Almodares and Hatamipour (6.00\%-16.06\%) [17]; Nandini et al. (7\%13\%) [4] and Salunkhe and Deshpande (5.8\%-10.4\%) [20]. Reducing sugars shown by this study (3.99\%-10.0\%) were specifically high when compared to those reported by Salunkhe and Deshpande (0.73\%-1.99\%) [20] and Nandini et al. (1\%-6\%) [4]. Total sugars were comparable to those reported by Rao et al. (12.6\%-16.4\%) [21]. The range of apparent purity in this study $(14 \%-76 \%)$ was close to that of Inman-Bamber (11.0\%-770\%) [22]; higher than that of Balole (16.6-38.8\%) [18] and lower than that of Mukabane et al. (33.89\%-83.91\%) [3]. Most of the materials studied gave pH values falling within the range reported in the literature i.e. Nandini et al. (4.7-5.5) [4]; Salunkhe and.Deshpande] (4.9-5.3) [20].

Identification of materials: As far as juice quality traits are concerned, sweet sorghum varieties showing high reducing sugars relative to sucrose content with brix greater than $15 \%$ are more preferred for syrup production $[16,4]$. Based on the results of this study, the exotic varieties: N100, Red-X, Hastings and N110 as well as the local Ankolib varieties: AnkNyala and Ank36 could have potential for syrup production. On the other hand, varieties suitable for sugar (jaggery) production require high purity (minimum of $75 \%$ ) with pol of $10 \%-14 \%$ and total sugars of $13 \%$ to $17 \%$ (i.e. relatively low reducing sugars) $[3,18]$. In this study, such requirements were more or less met by the exotic varieties: BlueRibbon, KansasCollies and Brawley. However, the latter showed moderate performance in purity $(65.2 \%)$.

The varieties BlueRibbon and Red-X were reported to have good performance in the yields of juice, stover and grain ([10]. Since the quality parameter of the juice was evaluated at the physiological maturity of the grain, the two varieties may have the potential for concurrent production of three products i.e. Jaggery or syrup, grain and stover (leaves and bagasse). Such results point to the possibility of combining high stem sugar, grain and stover yields in one cultivar, however, in Sudan, 
emphasis should be placed on grain for food rather than for feed, a choice which is not offered by the exotic cultivars but largely met by the local materials, specially Abu Sabin group, which unfortunately, of low sugar yield. Therefore, a local x exotic crossing project was started by the Forage Improvement Program (FIP) to transfer the desired traits from exotic to local materials by selection in the filial generation. Very promising materials in F5 generation are now accumulating with attributes matching the project objectives.

\section{Conclusions}

The study revealed some exotic and local (Ankolib) sweet sorghum varieties having juice quality parameters suitable for syrup and/or sugar (jaggery) production in the Sudan. Interaction of variety $\mathrm{x}$ season and yield parameters for juice, grain and stover should be considered when determining the choice of the variety. Future research should focus on developing multi-purpose varieties capable of concurrent production of syrup/sugar, grain and stover.

\section{Conflict of Interest}

The authors declare that there is no conflict of interest.

Table 2. Mean squares from single ANOVA for different traits of sweet sorghum varieties grown in summer and winter Seasons

\begin{tabular}{|c|c|c|c|c|c|c|}
\hline $\begin{array}{l}\text { Source of } \\
\text { variation }\end{array}$ & d.f. & Brix (\%) & Pol (\%) & $\begin{array}{l}\text { Reducing Sugars } \\
(\%)\end{array}$ & $\begin{array}{l}\text { Total Sugars } \\
(\%)\end{array}$ & $\mathrm{pH}$ \\
\hline \multicolumn{7}{|c|}{ Summer Season } \\
\hline Rep & 1 & 60.058 & 22.147 & 0.6002 & 15.455 & 0.000209 \\
\hline Genotype & 28 & $21.628 * *$ & $39.405^{* *}$ & $5.3921 * *$ & $26.951 * *$ & $0.084890 * *$ \\
\hline Residual & 28 & 6.011 & 1.823 & 0.6645 & 2.383 & 0.003748 \\
\hline \multicolumn{7}{|c|}{ Winter Season } \\
\hline Rep & 1 & 1.320 & 8.44 & 2.442 & 19.97 & 0.037257 \\
\hline Genotype & 28 & $15.893 * *$ & $32.43 * *$ & $4.669 * *$ & $25.89^{*}$ & $0.089412 * *$ \\
\hline Residual & 28 & 1.296 & 10.25 & 1.364 & 11.17 & 0.003432 \\
\hline
\end{tabular}

Table 3. Mean squares from combined ANOVA for different traits of sweet sorghum varieties grown in summer and winter Seasons

\begin{tabular}{lllllll}
\hline $\begin{array}{l}\text { Source of } \\
\text { variation }\end{array}$ & d.f. & Brix (\%) & Pol (\%) & $\begin{array}{l}\text { Reducing Sugars } \\
(\%)\end{array}$ & $\begin{array}{l}\text { Total Sugars } \\
(\%)\end{array}$ & $\mathrm{pH}$ \\
\hline Season $((\mathrm{E})$ & 1 & 16.440 & 6.289 & 18.881 & 46.965 & 0.306221 \\
Residual & 2 & 30.689 & 15.295 & 1.521 & 17.711 & 0.018733 \\
Genotype (G) & 28 & $30.453^{* *}$ & $61.389^{* *}$ & $6.340^{* *}$ & $43.291^{* *}$ & $0.162102^{* *}$ \\
GxE & 28 & $7.068^{*}$ & $10.445^{*}$ & $3.722^{* *}$ & 9.550 & $0.012199^{* *}$ \\
Residual & 56 & 3.653 & 6.039 & 1.014 & 6.778 & 0.003590 \\
\hline
\end{tabular}


Table 4. Brix (\%) values obtained by exotic and local sweet sorghum varieties in the winter and summer seasons (Shambat, 2012)

\begin{tabular}{llll}
\hline Variety & Winter & Summer & Combined \\
\hline AGSilo200 & 16.31 & 13.81 & 15.06 \\
Ank18 & 16.95 & 19.02 & 17.99 \\
Ank36 & 18.61 & 18.90 & 18.75 \\
Ank43 & 12.32 & 12.35 & 12.34 \\
AnkNyala & 14.58 & 20.66 & 17.62 \\
BlueRibbon & 20.59 & 22.19 & 21.39 \\
Brawley & 20.80 & 22.04 & 21.42 \\
Colman & 19.49 & 16.75 & 18.12 \\
E-35-1 & 18.52 & 18.85 & 18.69 \\
Fremont & 16.21 & 12.89 & 14.55 \\
Hastings & 18.61 & 18.53 & 18.57 \\
Kambal & 12.21 & 13.39 & 12.80 \\
KansasCollies & 20.88 & 20.39 & 20.63 \\
N100 & 20.53 & 16.29 & 18.41 \\
N110 & 20.80 & 18.40 & 19.60 \\
N98 & 16.25 & 15.68 & 15.97 \\
N99 & 16.46 & 18.19 & 17.33 \\
Red-X & 20.08 & 17.41 & 18.74 \\
S.126 & 14.36 & 16.46 & 15.41 \\
S.134 & 14.17 & 13.64 & 13.90 \\
S.154 & 12.94 & 16.60 & 14.77 \\
S.158 & 16.13 & 13.48 & 14.81 \\
S.70 & 12.29 & 10.91 & 11.60 \\
SG12-1 & 15.05 & 11.17 & 13.11 \\
SG32-2a & 15.84 & 13.28 & 14.56 \\
SG33 & 14.42 & 14.79 & 14.61 \\
SG54 & 14.76 & 12.16 & 13.46 \\
SugarDrip & 17.59 & 11.33 & 14.46 \\
Waconia-L & 19.63 & 15.99 & 17.81 \\
\hline Mean & 16.81 & 16.05 & 16.43 \\
SE \pm & 0.805 & 1.734 & 0.956 \\
LSD (0.05) & 2.332 & 5.022 & 2.707 \\
CV (\%) & 6.8 & 15.3 & 11.6 \\
\hline & & & \\
& &
\end{tabular}


Table 5. Pol (\%) obtained by exotic and local sweet sorghum varieties in the winter and summer seasons (Shambat, 2012)

\begin{tabular}{|c|c|c|c|}
\hline Variety & Winter & Summer & Combined \\
\hline AGSilo200 & 9.74 & 8.70 & 9.22 \\
\hline Ank18 & 7.07 & 9.03 & 8.05 \\
\hline Ank36 & 12.04 & 10.81 & 11.42 \\
\hline Ank43 & 1.47 & 4.80 & 3.14 \\
\hline AnkNyala & 5.95 & 13.54 & 9.74 \\
\hline BlueRibbon & 14.95 & 17.80 & 16.37 \\
\hline Brawley & 11.72 & 16.64 & 14.18 \\
\hline Colman & 8.88 & 5.54 & 7.21 \\
\hline E-35-1 & 7.07 & 9.67 & 8.37 \\
\hline Fremont & 6.94 & 6.76 & 6.85 \\
\hline Hastings & 11.74 & 11.26 & 11.50 \\
\hline Kambal & 3.18 & 7.16 & 5.17 \\
\hline KansasCollies & 15.71 & 15.05 & 15.38 \\
\hline N100 & 10.18 & 9.57 & 9.87 \\
\hline N110 & 15.02 & 7.21 & 11.11 \\
\hline N98 & 9.44 & 6.27 & 7.86 \\
\hline N99 & 9.07 & 7.26 & 8.16 \\
\hline Red-X & 12.09 & 9.57 & 10.83 \\
\hline S. 126 & 3.18 & 2.79 & 2.98 \\
\hline S. 134 & 4.01 & 5.05 & 4.53 \\
\hline S. 154 & 2.26 & 1.65 & 1.96 \\
\hline S. 158 & 7.70 & 4.46 & 6.08 \\
\hline S.70 & 3.71 & 0.94 & 2.33 \\
\hline SG12-1 & 4.55 & 2.19 & 3.37 \\
\hline SG32-2a & 8.75 & 4.99 & 6.87 \\
\hline SG33 & 4.22 & 2.80 & 3.51 \\
\hline SG54 & 6.90 & 1.75 & 4.32 \\
\hline SugarDrip & 3.43 & 5.74 & 4.58 \\
\hline Waconia-L & 11.46 & 9.89 & 10.68 \\
\hline Mean & 8.01 & 7.55 & 7.78 \\
\hline $\mathrm{SE} \pm$ & 2.264 & 0.955 & 1.229 \\
\hline LSD (0.05) & 6.560 & 2.766 & 3.481 \\
\hline CV (\%) & 40.0 & 17.9 & 31.6 \\
\hline
\end{tabular}


Table 6. Reducing Sugars (\%) obtained by exotic and local sweet sorghum varieties in the winter and summer seasons (Shambat, 2012)

\begin{tabular}{|c|c|c|c|}
\hline Variety & Winter & Summer & Mean \\
\hline AGSilo200 & 6.20 & 4.20 & 5.20 \\
\hline Ank18 & 7.35 & 4.20 & 5.78 \\
\hline Ank36 & 4.50 & 5.85 & 5.18 \\
\hline Ank43 & 7.50 & 6.20 & 6.85 \\
\hline AnkNyala & 8.35 & 5.35 & 6.85 \\
\hline BlueRibbon & 4.70 & 3.20 & 3.95 \\
\hline Brawley & 4.70 & 3.65 & 4.18 \\
\hline Colman & 9.00 & 5.85 & 7.43 \\
\hline E-35-1 & 7.35 & 6.20 & 6.78 \\
\hline Fremont & 6.20 & 5.00 & 5.60 \\
\hline Hastings & 6.70 & 6.70 & 6.70 \\
\hline Kambal & 5.85 & 5.85 & 5.85 \\
\hline KansasCollies & 4.65 & 3.80 & 4.23 \\
\hline N100 & 10.00 & 5.35 & 7.68 \\
\hline N110 & 5.70 & 7.35 & 6.53 \\
\hline N98 & 6.20 & 4.70 & 5.45 \\
\hline N99 & 6.70 & 6.15 & 6.43 \\
\hline Red-X & 6.70 & 6.70 & 6.70 \\
\hline S.126 & 6.70 & 9.00 & 7.85 \\
\hline S.134 & 6.50 & 8.35 & 7.43 \\
\hline S. 154 & 10.00 & 10.00 & 10.00 \\
\hline S.158 & 6.70 & 9.00 & 7.85 \\
\hline S.70 & 5.35 & 6.20 & 5.78 \\
\hline SG12-1 & 7.35 & 5.00 & 6.18 \\
\hline SG32-2a & 5.85 & 6.20 & 6.03 \\
\hline SG33 & 5.85 & 6.20 & 6.03 \\
\hline SG54 & 6.70 & 6.70 & 6.70 \\
\hline SugarDrip & 10.00 & 4.50 & 7.25 \\
\hline Waconia-L & 6.50 & 5.00 & 5.75 \\
\hline Mean & 6.75 & 5.95 & 6.35 \\
\hline $\mathrm{SE} \pm$ & 0.826 & 0.576 & 0.5035 \\
\hline LSD (0.05) & 2.392 & 1.670 & 1.4264 \\
\hline CV $(\%)$ & 17.3 & 13.7 & 15.9 \\
\hline
\end{tabular}


Table 7. Total sugars (\%) obtained by exotic and local sweet sorghum varieties in the winter and summer seasons (Shambat, 2012)

\begin{tabular}{|c|c|c|c|}
\hline Variety & Winter & Summer & Combined \\
\hline AGSilo200 & 15.94 & 12.90 & 14.42 \\
\hline Ank18 & 14.41 & 13.23 & 13.82 \\
\hline Ank36 & 16.54 & 16.66 & 16.60 \\
\hline Ank43 & 8.97 & 11.00 & 9.98 \\
\hline AnkNyala & 14.30 & 18.88 & 16.59 \\
\hline BlueRibbon & 19.65 & 21.00 & 20.32 \\
\hline Brawley & 16.41 & 20.29 & 18.35 \\
\hline Colman & 17.88 & 11.39 & 14.63 \\
\hline E-35-1 & 14.42 & 15.86 & 15.14 \\
\hline Fremont & 13.14 & 11.76 & 12.45 \\
\hline Hastings & 18.43 & 17.96 & 18.20 \\
\hline Kambal & 9.02 & 13.01 & 11.02 \\
\hline KansasCollies & 20.35 & 18.85 & 19.60 \\
\hline N100 & 20.17 & 14.92 & 17.55 \\
\hline N110 & 20.71 & 14.56 & 17.64 \\
\hline N98 & 15.64 & 10.97 & 13.30 \\
\hline N99 & 15.77 & 13.41 & 14.59 \\
\hline Red-X & 18.79 & 16.27 & 17.53 \\
\hline S.126 & 9.88 & 11.79 & 10.83 \\
\hline S. 134 & 10.51 & 13.40 & 11.95 \\
\hline S. 154 & 12.26 & 11.65 & 11.96 \\
\hline S. 158 & 14.40 & 13.46 & 13.93 \\
\hline S.70 & 9.06 & 7.14 & 8.10 \\
\hline SG12-1 & 11.90 & 7.19 & 9.54 \\
\hline SG32-2a & 14.60 & 11.18 & 12.89 \\
\hline SG33 & 10.07 & 9.00 & 9.54 \\
\hline SG54 & 13.59 & 8.45 & 11.02 \\
\hline SugarDrip & 13.43 & 10.23 & 11.83 \\
\hline Waconia-L & 17.96 & 14.89 & 16.43 \\
\hline Mean & 14.77 & 13.49 & 14.13 \\
\hline $\mathrm{SE} \pm$ & 2.364 & 1.092 & 1.302 \\
\hline LSD (0.05) & 6.847 & 3.162 & 3.688 \\
\hline CV $(\%)$ & 22.6 & 11.4 & 18.4 \\
\hline
\end{tabular}


Table 8. Purity (\%) obtained by exotic and local sweet sorghum varieties in the winter and summer seasons (Shambat, 2012)

\begin{tabular}{|c|c|c|c|}
\hline Variety & Winter & Summer & Mean \\
\hline AGSilo200 & 59.39 & 72.24 & 65.82 \\
\hline Ank18 & 42.16 & 47.51 & 44.84 \\
\hline Ank36 & 64.76 & 57.24 & 61.00 \\
\hline Ank43 & 11.90 & 37.62 & 24.76 \\
\hline AnkNyala & 41.05 & 65.48 & 53.27 \\
\hline BlueRibbon & 72.50 & 80.00 & 76.25 \\
\hline Brawley & 54.98 & 75.41 & 65.20 \\
\hline Colman & 45.49 & 32.94 & 39.22 \\
\hline E-35-1 & 35.88 & 51.13 & 43.51 \\
\hline Fremont & 42.92 & 57.19 & 50.06 \\
\hline Hastings & 63.24 & 60.90 & 62.07 \\
\hline Kambal & 24.40 & 52.71 & 38.55 \\
\hline KansasCollies & 75.19 & 73.81 & 74.50 \\
\hline N100 & 49.31 & 58.65 & 53.98 \\
\hline N110 & 72.18 & 39.16 & 55.67 \\
\hline N98 & 57.91 & 39.88 & 48.90 \\
\hline N99 & 54.35 & 39.29 & 46.82 \\
\hline Red-X & 60.20 & 54.79 & 57.49 \\
\hline S.126 & 21.88 & 16.94 & 19.41 \\
\hline S.134 & 26.67 & 36.94 & 31.80 \\
\hline S. 154 & 18.65 & 9.84 & 14.25 \\
\hline S. 158 & 47.37 & 33.15 & 40.26 \\
\hline S.70 & 28.62 & 7.24 & 17.93 \\
\hline SG12-1 & 30.11 & 19.10 & 24.60 \\
\hline SG32-2a & 55.26 & 37.05 & 46.15 \\
\hline SG33 & 29.70 & 19.07 & 24.39 \\
\hline SG54 & 46.71 & 16.10 & 31.40 \\
\hline SugarDrip & 19.10 & 51.17 & 35.14 \\
\hline Waconia-L & 58.41 & 62.93 & 60.67 \\
\hline Mean & 45.18 & 45.02 & 45.10 \\
\hline $\mathrm{SE} \pm$ & 12.66 & 7.51 & 7.36 \\
\hline $\operatorname{LSD}(0.05)$ & 36.66 & 21.75 & 20.84 \\
\hline CV $(\%)$ & 39.6 & 23.6 & 32.6 \\
\hline
\end{tabular}


Table 9. $\mathrm{pH}$ values obtained by exotic and local sweet sorghum varieties in the winter and summer seasons (Shambat, 2012)

\begin{tabular}{|c|c|c|c|}
\hline Variety & Winter & Summer & Combined \\
\hline AGSilo200 & 5.260 & 5.425 & 5.343 \\
\hline Ank18 & 5.245 & 5.460 & 5.353 \\
\hline Ank36 & 5.365 & 5.355 & 5.360 \\
\hline Ank43 & 5.420 & 5.470 & 5.445 \\
\hline AnkNyala & 5.370 & 5.410 & 5.390 \\
\hline BlueRibbon & 5.110 & 5.105 & 5.107 \\
\hline Brawley & 5.000 & 5.160 & 5.080 \\
\hline Colman & 5.115 & 5.420 & 5.268 \\
\hline E-35-1 & 5.330 & 5.470 & 5.400 \\
\hline Fremont & 5.175 & 5.250 & 5.213 \\
\hline Hastings & 5.150 & 5.165 & 5.158 \\
\hline Kambal & 5.685 & 5.770 & 5.728 \\
\hline KansasCollies & 4.950 & 4.945 & 4.947 \\
\hline N100 & 5.205 & 5.415 & 5.310 \\
\hline N110 & 5.165 & 5.430 & 5.297 \\
\hline N98 & 5.010 & 5.060 & 5.035 \\
\hline N99 & 5.035 & 5.035 & 5.035 \\
\hline Red-X & 5.195 & 5.250 & 5.223 \\
\hline S.126 & 5.845 & 5.640 & 5.742 \\
\hline S.134 & 5.675 & 5.640 & 5.658 \\
\hline S. 154 & 5.530 & 5.620 & 5.575 \\
\hline S.158 & 5.350 & 5.595 & 5.473 \\
\hline S.70 & 5.460 & 5.545 & 5.502 \\
\hline SG12-1 & 5.465 & 5.580 & 5.522 \\
\hline SG32-2a & 5.355 & 5.515 & 5.435 \\
\hline SG33 & 5.350 & 5.540 & 5.445 \\
\hline SG54 & 5.345 & 5.565 & 5.455 \\
\hline SugarDrip & 5.265 & 5.490 & 5.378 \\
\hline Waconia-L & 5.220 & 5.300 & 5.260 \\
\hline Mean & 5.298 & 5.401 & 5.349 \\
\hline $\mathrm{SE} \pm$ & 0.04142 & 0.04329 & 0.02996 \\
\hline $\operatorname{LSD}(0.05)$ & 0.12000 & 0.12540 & 0.08487 \\
\hline CV (\%) & 1.1 & 1.1 & 1.1 \\
\hline
\end{tabular}

\section{References}

[1] A. Bibi, H. A. Sadaqat, H. M. Akram, M. I. Mohammed, Physiological markers for screening sorghum (Sorghum bicolor L. Moench) germplasm under water stress conditions, International Journal of Agriculture and Biology. 12 (2010) 451-455.

[2] L. R. House, Sorghum: One of the world's great cereals, J. African Crop Sci. 2(1995)135-142.

[3] B. G. Mukabane, G. Thiongo, B. Gathitu, H. Murage, N. O. Ojijo, W. O. Owino, Evaluating the potential of juice from some sweet sorghum varieties grown in Kenya to crystallize, Food Science and Quality Management. 30 (2014) 31-39.

[4] N. Nandini, N.M. Kolekar, J. H. Akade, A. K. Rajvanshi, Syrup production from sweet sorghum. Nimbkar Agricultural Research Institute (NARI), Phaltan. (2006) Available at:

https://www.researchgate.net/publication/238449544_Syrup_Production_from_Sweet_Sorghum 
[5] V. S. B. Reddy, K. A. Ashok, R. P. Sanjana, Sweet sorghum: A dry land-adapted, pro-poor bioethanol feedstock yielding both grain and fuel (2010), Available from www.icrisat.cgiar.org

[6] A. Beldados, L. Constantini, Sorghum exploitation at Kassala and its environs, North Eastern Sudan in the second and first millennia BC, Nyame Akuma. 75 (2011) 33-39.

[7] D. Q. Fuller, Early Kushite agriculture: Archaeobotanical evidence from Kawa, Sudan and Nubia. 8 (2004) 70-74.

[8] P.K.E. Rao, M. M.H. Mengesha, Sorghum and millet germoplasm collection in Eastern Sudan, Progress Report, Genetic Resources-16 (1979). ICRISAT, India.

[9] M. I. Mohammed, M. A. Mohamed, Evaluation of newly developed sweet sorghum (Sorghum bicolor) genotypes for some forage attributes, American-Eurasian J. Agric. \& amp; Environ. Sci. 6 (2009) 434-440.

[10] S. I. Abdalbagi, M. I. Mohammed, Concurrent improvement of stem sugar, stover and grain yield in Sudanese and exotic sorghums i: Identification of materials, Journal of Advances in Biology \& Biotechnology. 17 (2018) 1-8.

[11] M. I. Mohammed, S. I. Abdalbagi, Concurrent improvement of stem sugar, stover and grain yield in Sudanese and exotic sorghums II: Heritability, genetic advance and association studies, Journal of Advances in Biology \& Biotechnology.17 (2018) 1-8.

[12] J. G. N. Gaskin, R. J. Mesley, The effect of basic lead acetate solution upon the optical rotation (polarization) of solutions of sucrose, fructose and glucose and of various mixtures of these solutions. Int. Sug. J. 60 (1958) 65-71.

[13] G. L. Miller, use of dinitrosalicylic acid reagent for determination of reducing sugar. Anal. Chem. 31 (1959) 426-428.

[14] W. G. Cochran, G. M. Cox, Experimental designs. 2nd edn. John Wiley and Sons, Inc. New York. (1957) 293-316.

[15] Genstat, Lawes Agricultural Trust (Rothamsted Experimental Station), VSN International, Ninth edition (2009) Version - 9.1.0.174. Hertfordshire. UK.

[16] A. M. Abd El-Razek, S.Y. Besheit, Potential of some sweet sorghum (Sorghum bicolor L. Moench) varieties for syrup and ethanol production in Egypt, Sugar Tech. 3 (2009) 239-245.

[17] A. Almodares, M.S. Hatamipour, Planting sweet sorghum under hot and dry climatic condition for bioethanol production. World Renewable Energy Congress. Bioenergy Technology (Be), (2011). Linköping, Sweden.

[18] T. V. Balole, Strategies to improve yield and quality of sweet sorghum as a cash crop for small scale farmers in Botswana, PhD theses (2001) University of Pretoria.

[19] D.B. Kulkarni, H.W. Deshpande, B.K. Sakhale, V.S. Pawar, Sweet sorghum syrup as natural sweetener for glazed tamarind candy, Int J Nutr Sci. 3 (2018) 1023.

[20] D.K. Salunkhe, S.S. Deshpande, Foods of plant origin: Production, technology, and human nutrition, In: Sugar Crops, Desai B. B. et al. (C) Van Nostrand Reinhold. (1999) 413-489.

[21] S. S. Rao, J. V. Patil, A. V. Umakanth, J. S. Mishra, C. V. Ratnavathi, G. S. Prasad, B. D. Rao, Comparative performance of sweet sorghum hybrids and open pollinated varieties for millable stalk yield, biomass, sugar quality traits, grain yield and bioethanol production in tropical Indian condition, Sugar Tech.15 (2013) 250-257.

[22] N. G. Inman-Bamber, an evaluation of sweet sorghum as a sugar crop in the Midlands Mistbelt, Proceedings of the South African Sugar Technologists' Association. (1980) Pp 105-108. 